buildings. Although the main supplies to each room are controlled by master switches at the door, the trunking ehannel runs through from room to room so that special circuits can be arranged to connect up apparatus in different laboratories without knocking holes in walls or breaking up concrete floors. At present each laboratory is provided with a $240-\mathrm{V}$. single-phase ring-main with a lavish supply of 13-amp. points. Threephase points are also fitted, and stabilized supplies of direct and alternating current are available in the Research Block.

The arrangements for supply of water, gas and compressed air also follow a scheme previously used by the architects. The pipe-work is enclosed by removable timber panelling, topped by a shelf $1 \mathrm{ft}$. wide running along the wall and level with the bench surfaces. The taps are mounted on this shelf, which also provides a useful extension to bench space. It has been found that a single sink is quite sufficient in a large laboratory, but taps and cone wastes must be fitted at regular intervals to provide water for cooling purposes.

The air for the building is filtered and heated before circulation. The main heating, which is thermostatically controlled, is provided by hot-water pipes running beneath the removable panels which form the ceiling. Radiators, which are unsightly and occupy valuable wall space, have been generally eliminated. The problem of providing space for the large horizontal ducts for the distribution of the heating, ventilation and other services over each floor of the teaching block has been overcome in an original manner. These ducts run along the centreline of the building in the ceilings, the latter being sloped upwards towards the outer walls so as to allow maximum window height. The large area of window space, which contributes much to the interior appear- ance of the building, is double-glazed in order to reduce heat losses and secure uniformity of temperature. The high level of natural illumination is supplemented in the teaching block by fluorescent lighting. This produces a certain amount of electrical interference which has been reduced to a minimum by the use of tungsten ballast lamps. In the research block, where no interference is allowable, tungsten lighting alone is used.

The research block has presented particular problems of design because of the difficulty in foreseeing future trends of research. A standard laboratory size of $40 \mathrm{ft}$. $\times 20 \mathrm{ft}$. has been adopted, but variety has been achieved by dividing a number of these rooms unequally so as to give laboratories $25 \mathrm{ft} . \times 20 \mathrm{ft}$. and $15 \mathrm{ft} . \times 20 \mathrm{ft}$. These are all grouped round a central hall, two storeys in height, which can accommodate very large apparatus. Extremely heavy floor loading is allowable here, and a special hard concrete surface is provided which does not produce dust. Floor-ducting of services is necessary in this case as also in the workshops. A helium return system, consisting of a pipe network for the collection of the gas given off by helium cryostats, extends to all laboratories in the research block. A number of rooms has been set aside for special purposes : an X-ray laboratory, a glass-blower's room, a rock-cutting room, an anechoic chamber, a store for radioactive materials and several photo. graphic dark rooms. In order to ensure maximum flexibility, however, an effort has been made to avoid specialization in laboratory design so far as possible.

The building forms a striking addition to the architecture of the University and the City. It demonstrates the possibility of satisfying both practical and rsthetic requirements within the stringent conditions imposed by present-day university finance.

\title{
OBITUARY
}

\section{Dr. A. Muir}

Sorr science suffered a great loss by the death on February 1 at Harpenden, Hertfordshire, of Alexander Muir, deputy director of Rothamsted Experimental Station and head of the Pedology Department and of the Soil Survey of England and Wales.

Born on September 12, 1906, he was educated at Leith Academy and the University of Edinburgh, where he graduated with first-class honours in chemistry in 1928. As a research scholar he was for a time at the Edinburgh and East of Scotland Colloge of Agriculture before going to the U.S.S.R., where he spent nearly two years at the Dokuchaev Institute of the Academy of Sciences, working with K. K. Gedroiz and B. B. Polynov, two of the most eminent Russian soil scientists. The Russians were pioneers in the infant science of pedology, and Muir was able to study at first hand their work on the soil-absorbing complex, their theories on soil genesis and their genetic system of soil classification which is based on the influence of climate, vegetation, parent material and other factors on the soil 'profile'. He also took part in a soil survey in the Crimea, thereby obtaining experience in the Russian methods of mapping. He made many lasting friendships, and the regard in which he was held by his Russian colleagues is evidenced by the fact that, at their invitation, he revisited the U.S.S.R. on three occasions since the War and was about to go again.

Muir returned home with his valuable Russian experience at a most opportune time. The Macaulay Institute for Soil Research had just been founded, and Muir was one of the small group of able young men who built up the reputation of the new Institute. The Department of Pedology, which he started, was the first in Great Britain, and his early field work developed into the Soil Survey of Scotland.

In 1945, Muir was invited to join the staff at Rothamsted to establish a Pedology Department and the following year he succeeded G. W. Robinson as head of the Soil Survey of England and Wales, the headquarters of which was then transferred to Rothamsted. From small beginnings, he built up the Soil Survey into a very efficient organization which has already mapped 7,500 square miles of England and Wales. He himself devoted much attention to the difficult problems of classification and correlation. At the same time he took a very active part in his Pedology Department, which attracted students from many countries, and he published a number of important papers, the last of which "The Podzol and Podzolic Soils" appeared recently in Advances in Agronomy. He became deputy director of Rothamsted in 1956 . 
Muir was the acknowledged authority on pedology and soil surveying in Britain, and his international reputation led to his advice and assistance being sought in many parts of the world. He became very interested in African soils and personally carried out the soil survey of the Shire Valley project in Nyasaland, publishing papers on this and on soils in Tanganyika. Other activities included an expedition to the Middle East in 1948 to study soils in relation to the corrosion of oil pipe-lines.

His keen interest in geochemistry was probably aroused by translating Polynov's book The Cycle of Weathering in 1937. Later, at the Macaulay Institute and at Rothamsted, he became closely associated with V. M. Goldschmidt, who had escaped from the Nazis in Norway and was engaged in writing what is now a standard treatise on geochemistry. Goldschmidt died before it was completed, and it would probably never have been published had not Muir undertaken to complete and edit it. This, in fact, involved compiling the book from Goldschmidt's very incomplete notes.

Muir took a prominent part in re-starting the International Society of Soil Science after the War, and was for a time president of the Commission dealing with Soil Genesis, Classification and Carto- graphy. He gave invaluable help to the Colonial Office, assisting them to establish their Pool of Soil Surveyors based on Rothamsted, and making personal visits to many territories where there were soil problems. For the U.N. Food and Agriculture Organization he undertook many duties and acted as chairman of several of their committees. He renewed his interest in the Middle East as a member of a working party on Land Classification and Soil Surveys and during the past three years attended meetings in Turkey, Iraq and Iran held under the auspices of the Central Treaty Organization. Just before his death he visited India as a member of a Unesco Committee on the establishment of a Contral Indian Institute for Pedology and Soil Mechanics.

Muir was a man of great vitality and vigour, equally at home in the field and the laboratory. Always ready to help others, he was held in affection and esteem by his colleagues and staff, and will be greatly missed, both as a scientist and as a man.

He married in 1934 Winifred, daughter of the late Prof. Drummond of the West of Scotland College of Agriculture, and the sympathy of their many friends will be extended to her and her two daughters. W. G. OGG

\section{NEWS and VIEWS}

\section{Henry Dale Research Professorship:}

Prof. J. L. Gowans

Prof. J. L. Gowans, Fellow and medical tutor, St. Catherine's College, Oxford, and a member of the external staff of the Medical Research Council at the Sir William Dunn School of Pathology, Oxford, has been appointed by the Council of the Royal Society as its first holder of the Henry Dale Research professorship of the Royal Society. The professorship was established last year following a gift of $£ 100,000$ from the trustees of the late Sir Henry Wellcome to the Royal Society. Prof. Gowans will continue his researches in immunology and experimental pathology. $\mathrm{He}$ is well known for his solution of the controversial problem of the fate of lymphocytes and his demonstration that the lymphocyte is an immunologically competent cell.

\section{Geology at Manchester :}

Prof. E. A. Vincent

Dr. E. A. VINCENT has recently been appointed to the chair of geology in the University of Manchester in succession to Prof. W. A. Deer, who has transferred to Cambridge (Nature, 189, 793; 1961). Dr. Vincent is one of those rare and valuable scientists who belong to two disciplines: in his case, chemistry and geology. In 1936 he went to the University of Reading, intending to be a geologist, but after three years, having taken the general degree course, the War began and he was directed into the school of chemistry. For most of the War years he was an explosives chemist in charge of plant in the Royal Ordnance Factory, Bishopton. He was determined, however, to return to geology, and the acute shortage of geologists after the War gave him his chance. He joined the D'Arcy Exploration Co. as an oil exploration geologist and was concerned with logging the deep boreholes then being put down in the North of England. In 1946 he was appointed to a nowly established lectureship in mineralogy and crystallography in the Durham Colleges (University of Durham), where ho started a small chemical laboratory for silicate analysis and began his studies in chemical mineralogy, for which he is now so well known. In 1951 he moved to Oxford to continue similar work, first as a University demonstrator, and since 1956 as reader in mineralogy.

Dr. Vincent's research has been firmly based on his chemical analyses of rocks and separated minerals. He has developed modern methods as they became available, and in recent years has pioneered the use in geology of neutron activation and radioactive tracer methods of analysis. His earliest work was on Tertiary dykes, particularly the nature of the residual liquids produced by crystal fractionation, and he has collaborated from the chemical side in the investigation of several other aspects of Tertiary igneous rocks. His detailed studies of the irontitanium minerals of the Skaergaard igneous complex, by analytical, optical and magnetic methods, have made him an authority on this group of minerals. Another of his interests is the distribution of trace elements, as determined by neutron activation; he has particularly worked on gold, silver, thallium and arsenic in differentiated igneous rocks. While $\mathrm{Dr}$. Vincent's research has been in the field of chemical mineralogy and petrology, he has always retained a great interest in geology as a whole, and all will wish him well in his new sphere as a professor of geology.

\section{U.S. Department of Commerce, National Bureau} of Standards :

Awards

DR. LEO A. WALL, of the U.S. National Bureau of Standards, has been awarded the Department of Commerce Gold Medal for Exceptional Service. A chemist in the Polymer Structure Section of the Bureau, Dr. Wall was honoured "in recognition of pioneering research in the synthesis of new fluoro. carbon compounds for the preparation of organic polymers"

Dr. H. W. Koch, chief of the High Energy Radia. tion Section of the National Bureau of Standards, has been awarded the U.S. Department of Commerce 